\title{
Traditional handicrafts of Punjab developed from plant and agro-waste materials
}

\author{
LALITA RANI AND KANWALJIT BRAR
}

Received: 14.07.2017; Revised: 05.11.2017; Accepted: 19.11.2017

See end of the paper for authors' affiliations

\section{LALITA RANI}

Department of Apparel and Textile

Science, College of Home Science,

Punjab Agricultural University,

LUDHIANA (PUNJAB) INDIA
ABSTRACT : Punjab has a rich tradition of arts and crafts. The traditional handicrafts of different types made from plant waste materials available in their vacinity were used in every household during the pre-independence period. Doaba and Majha were faster to adapt to the modern life style, while Malwa region with low literacy level continued with the traditional ways of life as well as craft making. But over the last two decades practice of handicraft making had sharp decline even in Malwa region. Thus, to document the valuable basketry craft, a sample of 180 respondents of rural women comprising of 60 women from each of the three selected districts of Malwa region namely, Ludhiana, Patiala and Bathinda, who had developed traditional handicrafts in their life-time was selected purposively. Older women were found to have made fifty or more traditional handicrafts from plant and agro-waste materials in their lifetime. All women used to carry out different activities of practicing craft in their leisure time such as spinning yarn on Charkha, weaving basketry products like Bohey/Chhikkoo, Katnee(s), etc. and embroidering the Phulkaris or baghs. The largest percentage of respondents (28.89\%) had made Bohey/Chhikkoo followed by 19.45 per cent respondents who had made Chhabi(an) from plant and waste materials. None of the respondents was now found to be making these handicrafts for domestic use.

KEY WORDS: Traditional handicrafts, Agro-waste materials

- HOW TO CITE THIS PAPER : Rani, Lalita and Brar, Kanwaljit (2017). Traditional handicrafts of Punjab developed from plant and agro-waste materials. Asian J. Home Sci., 12 (2) : 583-587, DOI: 10.15740/ HAS/AJHS/12.2/583-587. 